\title{
Evaluating Competency Enhancement Needs of Lecturers for Quality Teaching and Learning in South-East Universities of Nigeria
}

\author{
Akanwa, U. N. \& Eluwa, I. O. \\ Department of Science Education, Michael Okpara University of Agriculture, Umudike, Abia State-Nigeria
}

\begin{abstract}
This study was a quest aimed at evaluating competency enhancement needs of lecturers for quality teaching and learning in South-East universities of Nigeria. Reviewed literatures revealed that there is a steady decline in the quality of university graduates; as such the researchers sought to find out possible inputs that could enhance and guarantee quality instructional delivery in our universities in particular and other tertiary institutions in general. The study adopted the survey research design and randomly sampled 372 respondents from six universities ( 3 federal and 3 states) who are academic staff. The results of data analysis using simple percentages and contingency Chi-square statistical analysis technique at $95 \%$ confidence interval revealed that above $90 \%$ of male and female lecturers opined that teaching staff are in dare need of competency enhancement inputs such as regular training workshops and conferences (local and international), functional ICT units for staff and students, inter and intra collaborative teaching experience amongst institutions within and outside the country for cross fertilization of ideologies and skills, and regular up-grading of teaching and learning facilities. The need for proactive funding of tertiary education was recommended. More so, the administrative echelons of higher institutions in Nigeria were encouraged to devise mechanisms of ensuring an updated pool of academic staff for qualitative pedagogical delivery.
\end{abstract}

Keywords: Evaluating Competency Enhancement Needs, Quality Teaching and Learning

\section{Introduction}

Human asset is one of the most important resources available to any organization, and employee competence as well as commitment largely determines the objectives that an organization can set for itself in relation to the extent she can achieve success in them. As such, the demand for effective employees continuously increases in both public and private organizations. The 'Competency-based' approach to human resource management has become integral during the last thirty years, with 'Competency' encompassing the knowledge, skills, abilities, traits and behaviors that allow an individual to perform a task within a specific function or job (Boyatzis, 1982).

The development of any nation depends much on the number of educated adults within the productive age; thus quality education is of great importance. The school and other institutions of learning are medium of social change created by the society to perform the important cultural functions associated with the education of the citizens. In order words, the educational institutions are the primary agents of change and developments.

Quality education as opined by Eluwa and Akanwa (2013), is one of the fundamental human rights of every citizen of a country. It is a basic tool in the development of human capacities and capabilities. But in the past decade, there have being series of outcries for quality education and educational reforms locally, nationally and the internationally (Kakwagh, 2013, Oladipo, Adeosun \& Oni, 2012).

A number of conferences, seminars, and workshops have been organized at international, national and local levels on issues aimed at addressing the numerous problems bedeviling the educational sector. This is as a result of the growing awareness that that the advancement of any nation is dependent on the quality of her citizenry.

Education is a core instrument of change that brings about innovations and inventions in any society because the creativity, resourcefulness, and imaginative abilities of learners are sharpened as they go through various stages of educational programs (Itedjere, 1997; Whawo, 1997). Thus, recognizing the transformative power of quality education is a prerequisite for the attainment of the much needed scientific and technological development in the developing nations of the world.

University education is one of the major drivers of economic competitiveness in an increasingly knowledgedriven global economy because of the obvious imperative for countries to improve the employment skills of her work force. National and transnational debates, direct state regulations or incentives, and competition among private and state-owned institutions all prompt tertiary institutions to put quality teaching on their agenda (Hénard, 2012).

As tertiary educational systems grow and diversify, society is increasingly concerned about the quality of her programs. Much attention is given to public assessments as well as international rankings of these institutions. 
Although these comparisons tend to overemphasize research, using research performance as a yardstick of institutional value; measuring teaching quality is a challenging task. Teaching ought not to be seen as increasingly relative to the research goals of an institution; rather educational institutions should to be recognized for being providers of good quality education particularly at the tertiary level of learning in order to actualize the much desired scientific and technological growth and development. As such, there is a need to find new ways of measuring and demonstrating performance.

Competencies in the views of Vathanophas and Thai-ngamare (2007) are the certain characteristics or abilities of an individual that enable them to perform appropriate specific actions. It represents the capability that an individual brings to the job and when the responsibilities of the job to produce the desired results require the demonstration of specific actions, the individual draws from inner resources for the capability to respond.

Competency enhancement on the other hand is a term used to describe measures taken within a course, program, or institution to enhance or strengthen quality (www.lfhe.ac.uk/governance/hefastfacts/jargon.html). It involves steps and measures taken by a person or groups of persons in order to heighten; increase, (especially to increase or improve in value) quality and desirability. Competency enhancement is a topic of great interest in today's' academic society and one of the tools we need to utilize if we are to solve the lingering problem facing the educational sector (Abiodun, 1997).

One of the guiding principles in ensuring quality assurance in any educational system is the recognition that education is a continuous interactive process. As such, teaching and $n$ learning activities should be tailored and guided by values aimed at sharpening and re- shaping the academic, social, personal and career growth of the participants. Thus, competency enhancement is a viable tool for sustaining an individual's ability to understand and function well in our educational system and an effective tool for addressing the re-curing decline in the quality of our educational outputs (Kayani, Morris, Azhar, \& Kayani, 2011).

Taking advantage of this tool generally require excerpts grasp of its' benefits even though it does require a distinctive approach to analyzing information which are impacted to an individual from time to time in order to equip such individual with the ability to make accurate observations, develop conjectures, and test hypotheses (Aguele, \& Kolawole, 2007). Therefore, it is imperative to evaluate competency enhancement needs of lecturers for quality teaching and learning in South East universities of Nigeria

\section{Literature review}

According to Vathanophas and Thai-ngamare (2007), competent employees are the main resource of any organization in acquiring a competitive advantage. Land, buildings or materials do not yield company productivity, rather, it is 'people capital' that runs a business and produces value from existing resources. HayGroup (2004) point out that an organization's best source of competitive advantage lies with its employees. Strategies, business models, products and services can all be copied by competitors, but talented and competent employees represent a sustainable source of differentiation.

Akuegwu, Ntukidem, and Jaja (2011) conducted a study on information and communication technology (ICT) facilities utilization for quality instructional services delivery among university lecturers in Akwa Ibom and Cross River State, in Nigeria. Results revealed that availability of ICT facilities for quality instructional service delivery in universities in Nigeria is significantly low and lecturers' utilization of ICT facilities is also significantly low.

Other studies have also confirmed that lack of computer skills exists among faculties in some universities in Nigeria. As such, they are unable to incorporate the benefits of computer technology in their teaching, research and service delivery to the university community. Less than 12 percent of the Nigerian academic curricula have digital content. This technology deficient therefore translates into a major handicap in effort to bridge Nigerian digital divide (Aniebonam, 2008).

A strategic study carried out on behalf of the EU commission showed that while the level of integration of ICT in teaching has increased greatly, considerably variations still exist between institutions in this regard (Ramboll, 2004). By implication the increase in the level of integration of ICT in teaching is not uniform. While some universities improve on their provisions of ICT facilities and consequently, their utilization in teaching/learning in the classrooms, others have remained stagnant and this has impacted negatively on their lecturers' utilization of ICT for instructional service delivery.

The demand for effective and competent employees continuously increases in both public and private organizations because the dynamic global marketplace and increasing foreign competition has compelled organizations to become more effective and flexible in response to the rapidly changing environment. As a result, this is a suitable time to assess and enhance human resource management (HRM) practices within the universities that can augment organizational performance (Gould-Williams, 2003). 


\section{Purpose of the study}

This study was designed to evaluate competency enhancement needs of lecturers for quality teaching and learning in tertiary institutions of Nigeria. Specifically, the study was a quest aimed at identifying and bringing to limelight the competency enhancement needs of lecturers for quality teaching and learning in SouthEast universities.

\section{Hypothesis}

The following null hypotheses were raised and tested in this study:

Ho $_{1}$ : The percentage of lecturers in South-East universities that need enhancement in their competency skill is not significantly high.

$\mathbf{H o}_{2}$ : Male and female lecturers in South-East universities do not significantly differ in their perception of competency enhancement needs in these institutions.

\section{Method}

This study used the survey research design. The area of the study; South-East Nigeria is a region of Nigeria that borders Cameroon to the east and the Atlantic Ocean to the south. It is the homeland of Kwa speaking people and the dominant language of this region is Igbo. It is primarily situated in the Niger Delta region of West Africa, where it meets the Atlantic Ocean to its South. It has lands on both sides of the lower Niger River although the larger chunk of the region is situated on the East of the river. The region is surrounded by a host of large rivers and plays host to five states namely Abia, Anambra, Ebonyi, Enugu, Imo, and state. The region has five federal and five state owned universities.

The population for this study consisted of all academic staff of the ten universities whether teaching on fulltime or part-time basis numbering about 5222. Six universities were selected using simple random sampling technique after which proportionate random sampling techniques was used to draw 62 academic staff from each of the selected institution (31 males and 31 females) given rise to a total sample size of 372 respondents used for the study. The states covered were Abia, Ebonyi, and Imo state.

A 20- items four- point Likert scale questionnaire tagged "Questionnaire Evaluating Competency Enhancement Needs of Lecturers for Quality Teaching and Learning in Nigerian Universities"'(QECENLQTLNU) was the instrument used for data collection. It was constructed by the researchers and validated by experts in instrument construction. The questionnaire had two sections. Section A sought the demographic variables of respondents while section B sought information on competency enhancement needs of lecturers within the university teaching and learning system in the last decade. Respondents were asked to indicate their level of agreement or disagreement with the statements. A rating from 1 indicating strongly disagrees to 4 strongly agree was used. The trial test results of the "QECENLQTLNU" instrument revealed that there were no ambiguities, and produced a Cronbach's Alpha reliability coefficient of 0.82 indicating a high internal consistency of the test items.

Data analysis was carried out using simple percentages and Chi- square statistical analysis techniques as presented below.

\section{Results}

Table 1: Percentage rating by lecturers of areas of competency enhancement needs for quality service delivery in south-east universities.

\begin{tabular}{|c|c|c|c|}
\hline Variable & $\begin{array}{l}\text { Male } \\
n=186\end{array}$ & $\begin{array}{l}\text { Female } \\
n=186\end{array}$ & $\begin{array}{c}\text { Decision } \\
\text { in }\end{array}$ \\
\hline & & & $\%$ \\
\hline Regular training workshops and conferences & 170 & 169 & 91.13 \\
\hline Functional ICT units for staff and students & 182 & 158 & 91.39 \\
\hline Collaborative teaching experience within and outside the country & 180 & 150 & 88.71 \\
\hline Regular up-grading of teaching and learning facilities & 184 & 170 & 95.16 \\
\hline
\end{tabular}

$* \mathrm{p}<.05$

In Table 1, the percentage rating by respondents of the QECENLQTLNU was analyzed in order to identify areas of competency enhancement needs of lecturers for quality service delivery in our institution of higher learning. The result shown on Table 1 revealed four strategic areas of competency enhancement needs for effective instructional delivery in our tertiary institutions. 
Table 2: Chi- square analysis of male and female lecturers' perception of competency enhancement needs in

\begin{tabular}{lllllllll} 
& \multicolumn{7}{c}{ south-east universities. } \\
\hline Gender & RTWC & FICT & CTE & RUTLF & N & Cal x $^{2}$ & df & Crit x $^{2}$ \\
\hline Male & 20 & 56 & 42 & 68 & 186 & & & 7.81 \\
& $(28)$ & $(50)$ & $(47)$ & $(61)$ & & 5.30 & 3 & \\
Female & 18 & 50 & 32 & 86 & 186 & & & \\
& $(22)$ & $(42)$ & $(38)$ & $(84)$ & & & & \\
\hline Total & 38 & 106 & 74 & 154 & 372 & &
\end{tabular}

$\mathrm{P}<0.05$; df 3 .

Comparing the calculated Chi-square value of 5.30 with the table value of 7.81 at 3 degree of freedom, and $95 \%$ confidence interval; we reject the null hypothesis that male and female lecturers in South East universities do not significantly differ in their perception of competency enhancement needs in these institutions. This outcome implies that gender significantly affect the perception of competency enhancement needs among university lecturers.

\section{Discussion}

The outcome of this study revealed that there were four competency enhancement need areas among lecturers in universities of South-East Nigeria. The four strategic areas of needs identified by this study includes regular training workshops and conferences (both local and international), functional ICT units for teachers and students, collaborative teaching experience within and outside the country, and regular up-grading of teachinglearning facilities among others. This result is closely linked with the works of Vathanophas and Thai-ngamare (2007) that identified twenty-three competencies that superior job performers used in carrying out their job well.

In addition, this this outcome of study further collaborates the works of Akuegwu, Ntukidem, and Jaja (2011) whose study revealed that availability of ICT facilities for quality instructional service delivery in universities in Nigeria is significantly low as such lecturers' utilization of ICT facilities is also significantly low.

Other studies which supported that lack of computer skills exists among faculties/colleges in some Nigerian universities include studies by Aniebonam, (2008). Aniebonam, (2008), found that less than 12 percent of the Nigerian academic curricula have digital content. This technology deficiency therefore translates into a major handicap in effort to bridge Nigerian digital divide as such academic staff are unable to incorporate the benefits of computer technology in their teaching, research and service delivery to the university community.

\section{Conclusion}

No dynamic teaching is possible without a dynamic teacher, and an effective teacher is known through his or her quality of teaching. The implications derived from the findings of this study suggests that there is altogether low competency enhancement strategies put on ground in most institutions of higher learning in Nigeria; as such this study is providing a more focused approach in identifying relevant professional development programs which could help to enhance academic staff competency in Nigerians' university so that quality instructional delivery could be guaranteed.

Competency enhancement strategies are pedagogical strategies targeted either at the teachers (teaching) or the students (learning) or occasionally both (work environment) aimed at enhancing the pedagogical process and ensuring quality assurance. The inability of education funding organizations or agencies; whom primarily are the Federal and State Government in this case to intervene pragmatically with these enhancement initiatives has posed serious problems in our universities and other institutions of higher learning over the years.

The wakeup call to all those involved in education related decision making is that proactive actions needed to enhance capacity in our institutions of learning generally are expedient if we are to save the educational sector. Some of these proactive actions should include regular training workshops and conferences (both local and international) for academic staff, functional ICT units for teachers and students, collaborative teaching experience within and outside the country, and regular up-grading of teaching-learning facilities among others.

\section{Recommendations}

Keeping in view the findings revealed and conclusions drawn in this study, the following recommendations were made to ensure quality instructional service delivery in this global ICT age.

- The universities and every departments/ colleges within the universities should incorporate competencies enhancement strategies into her future competency-based human resource management plan for qualitative teaching and learning research experiences.

- The federal and state government should as a matter of priority increase their funding of universities education in accordance to the recommendations of UNESCO which will invariably enable the university administrators to provide more of these pedagogical enhancement training and facilities.

- Modalities should be put in motion to enable university lecturers acquire continuing or in-service education which are continuous professional development program for enhancement of professional skills. The in- 
service education programs are periodical teaching workshops specific to academic staff which could be optional or mandatory targeted at new or current lecturers in order to update their instructional skills. These periodic programs have the capacity of equipping and enabling university teachers enrich their content knowledge through searching for more and new materials make learning more meaningful and improve students' learning outcomes.

\section{References}

[1] Boyatzis, R. (1982). The Competent Manager: A Model for Effective Performance. NewYork: John Wiley \& Sons. (2)

[2] Eluwa, I. O. \& Akanwa, U. N. (2013). Appraising impact of school quality on instructional academy of education, 8, (1), 96-110. (2)

[3] Kakwagh, V. V. (2013). Declining quality of intellectual output in Nigeria's tertiaryinstitutions of learning: The underlining existential factors. .Journal of Education and Practice, 4, (11), 34-38.(2)

[4] Oladipo, A., Adeosun, O. \& Oni, O. (2012). Quality assurance and sustainable university education in Nigeria, Faculty of Education University of Lagos Akoka -Lagos Nigeria 109-125. Retrieved on 12 September 2013 from aadcice.hiroshimau.ac.jp/e/research/paper_no9-1.pdf. (2)

[5] Itedjere, P.O. (1997). History of education. Benin City, Nigeria: Osasu Publication.(2)

[6] Whawo, D.D. (1997). An introduction to the study of education (2nd ed.). Benin City: World of Books Publication. (2)

[7] Hénard , F. (2012). Learning our lesson: Review of quality teaching higher education. Retrieved on $12^{\text {th }}$ September 2013 from http://www.oecd.org/edu/imhe/qualityteaching (2)

[8] Vathanophas, V. \& Thai-ngam, J. (2007). Competency requirements for effective job performance in the public sector, Contemporary Management Research, 3 , (1), 45-70.(3)

[9] Abiodun, R.F. A. (1997).' The challenges of mathematics in Nigeria's economic goals vision 2011',.Keynote Address Presented at $34^{\text {th }}$ Annual National Conference of the Mathematical Association of Nigeria, Sept. 1-6.(3)

[10] Kayani, M. M., Morris, D., Azhar, M. \& Kayani, A. (2011).Analysis of professional competency enhancement program of NAHE on the performance of college teachers, International Journal of Business and Social Science, 2, (18), 23-29.(3)

[11] Aguele, L. A. Kolawole, O. U. (2007).Mathematics education for dynamic economy in the $21^{\text {st }}$ century. Journal of Social Science, 15(3), 293-296. (3)

[12] HayGroup. (2004). Hay Resources Direct. http://www.hayresourcesdirect.haygroup.com/Competency/Assessments_Surveys/Manager_Comp. (3)

[13] Akuegwu, B. A., Ntukidem, E. P, \& Jaja, G. (2011). Information and communication technology (ICT) facilities' utilization for quality instructional service delivery among university lecturers in Nigeria. Review of Higher Education in Africa, 3, (1), 123-129. (4)

[14] Aniebonam, M. (2008, May 22). UNIBEN AfriHUB centre opens, students praise VC. Retrieved from file http://www.ngrguardiannews.com on 10/3/2010. (4)

[15] Ramboll, P. L. S. (2004). Studies in the context of the e-learning initiative. Virtual modes of European Universities. Draft Final Report to the E. U. Commission. Capenhagen: DF Education and culture. (4)

[16] Gould-Williams, J. (2003). The Importance of HR Practices and Workplace Trust in Achieving Superior Performance: A Study of Public-Sector Organizations. International Journal of Human Resource Management, 14, (1) 28-54.(4) 